\title{
Kolonisasi Makrozoobentos pada Kolam Habitat Semi Ex Situ (HSE) di Kawasan Maninjau, Sumatera Barat
}

\author{
Aiman Ibrahim ${ }^{*}$, Imroatushshoolikhah ${ }^{2}$, Yoyok Sudarso ${ }^{3}$, Lukman $^{4}$, \\ Muhammad Suhaemi Syawal ${ }^{5}$ \\ *e-mail: aiman@limnologi.lipi.go.id. \\ 1,2,3,4,5 Pusat Penelitian Limnologi \\ Lembaga Ilmu Pengetahuan Indonesia
}

\begin{abstract}
Semi Ex-Situ Habitat (HSE) Pond is a pond that is designed for spawning native fish in Lake Maninjau, particularly in Bada fish (Rasbora argyrotaenia) in semi ex situ condition. This study aims to determine the benthic macroinvertebrates colonization in HSE ponds. The source of the water came from Lake Maninjau and the springs nearby. The study was conducted in August, October, and November 2018. Benthic macroinvertebrates samples were taken from some artificial substrate stainless steelwire mesh (the size are $20 \mathrm{~cm} \times 20 \mathrm{~cm}$, mesh size 30), which was placed at the bottom of the ponds for $20-30$ days. The result shows that there are five classes of benthic macroinvertebrates in an HSE pond with the water springs and HSE pond with the water of Lake Maninjau. Chironomidae was the most abundant Family in both the springs-HSE pond and the lake Maninjau-HSE pond. The abundance of benthic macroinvertebrates in these two ponds respectively, are 2207 individuals $/ \mathrm{m}^{2}$ and 4138 individuals $/ \mathrm{m}^{2}$. The Shanon-Wiener diversity index value is low, they are 0,38 in the springs-HSE pond and 0,29 in the lake Maninjau-HSE pond. The Bray Curtis similarity index values in those two HSE Ponds ranged from $47 \%$ to $63 \%$, furthermore its categories from "not similar to similar".
\end{abstract}

Keywords: abundance, benthic macroinvertebrates, diversity, HSE pond, Maninjau area

\section{ABSTRAK}

Kolam Habitat Semi Ex Situ (HSE) merupakan kolam yang didesain untuk pemijahan ikan asli perairan Danau Maninjau terutama ikan bada (Rasbora argyrotaenia) secara semi ex situ. Penelitian ini bertujuan untuk mengetahui kolonisasi makrozoobentos di Kolam HSE dengan air yang bersumber dari mata air dan Danau Maninjau. Penelitian dilakukan pada bulan Agustus, Oktober, dan November 2018 melalui pengambilan sampel makrozoobentos pada substrat artifisial berupa bingkai stainless steelwire mesh (berukuran $20 \mathrm{~cm} \times 20 \mathrm{~cm}$; mesh size 30) yang didedahkan di bagian dasar kolam selama 20-30 hari. Berdasarkan hasil penelitian, secara keseluruhan ditemukan lima kelas makrozoobentos di Kolam HSE MA dan Kolam HSE DM. Insekta Chironomidae memiliki nilai kelimpahan tertinggi di Kolam HSE MA dan Kolam HSE DMmasing-masing sebesar 2207 individu $/ \mathrm{m}^{2}$ dan 4138 individu $/ \mathrm{m}^{2}$. Nilai indeks keanekaragaman Shanon-Wiener tergolong rendah dengan nilai 0,38 di Kolam HSE MA dan 0,29 di Kolam HSE DM. Nilai indeks similaritasBray Curtis di kedua Kolam HSE berkisar 47\% — 63\% dengan kategori tidak mirip hingga mirip.

Kata Kunci: kawasan Maninjau, keanekaragaman, kelimpahan, kolam HSE, makrozoobentos 


\section{PENDAHULUAN}

Perairan Danau Maninjau
merupakan danau alami tektovulkanik yang terletak di Kabupaten Agam Provinsi Sumatera Barat. Danau Maninjau dengan luas 99,5 $\mathrm{km}^{2}$ dimanfaatkan oleh masyarakat sekitar untuk kegiatan perikanan, pertanian, pariwisata, dan sarana Pembangkit Listrik Tenaga Air (PLTA). Kegiatan perikanan merupakan salah satu bentuk pemanfaatan utama perairan Danau Maninjau, baik perikanan tangkap maupun perikanan budidaya dengan sistem Keramba Jaring Apung (KJA). Berbagai kegiatan di sekitar danau berpotensi menurunkan kualitas air danau yang dapat mempengaruhi kehidupan biota akuatik salah satunya ikan.

Danau Maninjau merupakan habitat bagi beragam jenis sumberdaya perikanan seperti ikan bada (Rasbora argyrotaenia). Ikan tersebut merupakan ikan komersial yang menjadi komoditas khas dengan kehadiran populasinya di habitat alami cenderung mengalami penurunan. Hal ini diduga terkait dampak penangkapan berlebih dan penurunan kualitas perairan Danau Maninjau (Lukman, 2017). Di lain pihak, pemerintah daerah telah menerbitkan Peraturan Bupati No. 22 Tahun 2009 yang membatasi jumlah keramba sebanyak 2 unit untuk setiap keluarga dengan jarak $50 \mathrm{~m}$ dari tepian danau.

Pengembangan sistem konservasi ikan bada sebagai ikan asli Danau Maninjau dapat dilakukan melalui pembuatan kolam Habitat Semi Ex Situ (HSE) di tepian danau sebagai wilayah alternatif untuk pemijahan. Kolam HSE merupakan adopsi dari teknik penangkapan ikan bada menggunakan alat tangkap berupa lukah di aliran sungai inlet danau yang menjadi wilayah ruaya pemijahan ikan bada. Kolam HSE terdiri dari dua kolam dengan sumber air yang berbeda yaitu air dari mata air sebagai sumber air utama dan air dari Danau
Maninjau sebagai antisipasi penurunan kuantitas air dari mata air. Evaluasi kinerja dari kolam tersebut dapat dilakukan salah satunya dengan mengidentifikasi kolonisasi biota makrozoobentos yang berpotensi sebagai sumber pakan alami bagi ikan bada.

Makrozoobentos merupakan kelompok invertebrata berukuran lebih dari $0,5 \mathrm{~mm}$ yang hidup di dasar perairan atau menempel pada substrat. Milner (1994) menyatakan bahwa makrozoobentos merupakan pengkoloni pertama pada biotope yang baru dibuat. Keberadaan makrozoobentos di perairan sangat penting karena berfungsi sebagai sumber pakan alami bagi ikan atau predator lainnya dan berperan dalam proses perombakan materi organik (Purwati, 2015). Sulistiyarto (2015) menyatakan bahwa pengukuran keanekaragaman makrozoobentos dapat digunakan untuk menilai kondisi perairan dan potensi dampaknya pada komunitas ikan yang makanan utamanya berupa makrozoobentos. Ikan air tawar dapat memanfaatkan makrozoobentos seperti serangga air untuk pakan alami, baik sebagai pakan utama maupun sebagai pakan pelengkap (Asyari, 2006).

Penelitian biota di perairan kolam memiliki keuntungan diantaranya struktur habitat di perairan kolam yang lebih sederhana dan terbatas bila dibandingkan habitat alami serta akses pengambilan sampel yang lebih mudah. Selain itu, jumlah spesies yang lebih sedikit dibandingkan habitat alami menyebabkan lebih mudahnya mengevaluasi distribusi spesies dan faktor lingkungan yang mempengaruhinya (Edia, 2013). Identifikasi spesies dan pola distribusi makrozoobentos dapat memberikan informasi untuk monitoring dan pelestarian ekosistem kolam.

Penelitian terkait kolonisasi makrozoobentos di perairan kolam telah dilakukan oleh Soro et.al. (2018) dan 
Orwa et.al. (2018). Soro et.al. (2018) melakukan penelitian pada substrat artifisial di perairan kolam tanpa ikan dengan air yang bersumber dari danau buatan. Penelitian yang sama dilakukan oleh Orwa et.al.(2018) pada substrat alami dengan air kolam yang bersumber dari danau alami. Tujuan penelitian ini adalah mengetahui kolonisasi makrozoobentos pada Kolam HSE dengan air yang bersumber dari mata air dan Danau Maninjau.

\section{BAHAN DAN METODE}

Penelitian dilakukan pada bulan Agustus, Oktober, dan November 2018 pada Kolam HSE Sumber Air Mata Air (MA) dan Kolam HSESumber Air Danau Maninjau (DM). Pengambilan sampel makrozoobentos dilakukan dengan mengadopsi dan memodifikasi constructed cage sampler (Loke et.al., 2010), yakni berupa substrat artifisial bingkai stainless steelwire-mesh (berukuran $20 \mathrm{~cm}$ x $20 \mathrm{~cm}$; mesh size 30) sebanyak 3-4 substrat yang telah didedahkan di bagian dasar kedua Kolam HSE selama 20-30 hari. Sampel makrozoobentos diambil dari setiap substrat dan diawetkan dalam larutan formalin $5 \%$. Tahap penyortiran dan identifikasi sampel makrozoobentos dilakukan di Laboratorium Makroinvertebrata Akuatik Pusat Penelitian Limnologi LIPI dengan mengacu pada buku Yule \& Sen (2004) dan Klemm (1995). Parameter kualitas air yang diukur meliputi parameter suhu, $\mathrm{pH}$, dan oksigen terlarut.

Kelimpahan makrozoobentos dihitung dengan menggunakan rumus sebagai berikut (Odum, 1996):

$$
\begin{aligned}
& \mathrm{K}=\frac{10000 \times a}{b} \\
& \mathrm{~K}=\text { kelimpahan makrozoobentos }
\end{aligned}
$$

$$
\begin{aligned}
& \mathrm{a}=\underset{\text { jumlah individu yang }}{\text { diperoleh (individu) }} \\
& \mathrm{b}=\text { luas permukaan substrat }\left(\mathrm{m}^{2}\right)
\end{aligned}
$$

(Nilai 10000 merupakan nilai konversi individu dari per $\mathrm{cm}^{2}$ menjadi per $\mathrm{m}^{2}$ )

Keanekaragaman taksa makrozoobentos dihitung dengan menggunakan indeks Shanon-Wiener sebagai berikut (Lee et.al., 1978) :

$$
\begin{aligned}
\mathrm{H}^{\prime}= & -\sum_{\mathrm{i}}^{\mathrm{t}} \frac{\mathrm{ni}}{\mathrm{N}} \ln \frac{\mathrm{ni}}{\mathrm{N}} \\
\mathrm{H}^{\prime} & =\begin{array}{l}
\text { indeks } \\
\text { komunitas }
\end{array} \\
\mathrm{T} & =\text { jumlah spesies } \\
\mathrm{ni} & =\text { jumlah individu dari masing- } \\
\mathrm{N} & =\text { masing spesies } \\
\mathrm{N} & =\text { jumlah seluruh individu }
\end{aligned}
$$

Nilai indeks Shanon-Wiener mempunyai kisaran nilai tertentu yang menunjukkan tingkat keanekaragaman diantaranya $\mathrm{H}^{\prime}<1$ keanekaragaman rendah, $1 \leq \mathrm{H}^{\prime} \leq 3$ keanekaragaman sedang, dan $\mathrm{H}^{\prime}>3$ keanekaragaman tinggi (Wilhm, 1968 dalam Mason, 1981).

Kesamaan taksa makrozoobentos dua kolam dihitung dengan menggunakan indeks similaritas Bray Curtis (Krebs, 1978). Koefisien similaritas ditentukan dengan nilai 1-B.

$B=\frac{\sum[X i j-X i k]}{\sum[X i j+X i k]}$

B = ukuran ketidaksamaan Bray-Curtis

$\mathrm{Xij}, \mathrm{Xik}=$ jumlah individu spesies ke-i dalam setiap contoh

$\mathrm{N}=$ jumlah spesies dalam contoh

\section{HASIL DAN PEMBAHASAN}

Berdasarkan pengamatan makrozoobentos yang dilakukan pada bulan Agustus hingga November 2018, 
Kolonisasi Makrozoobentos pada ........Aiman I., Imroatushshoolikhah, Yoyok S., Lukman, Muhammad S. S.,...Sainmatika,...Volume 17,...No. 1,...Juni 2020,...36-45

telah ditemukan 4-10 taksa makrozoobentosdi Kolam HSE MA (Gambar 1). Taksa tersebut termasuk kelompok Insekta Akuatik, Ostracoda, Gastropoda, Oligochaeta, dan Euhirudinae (Gambar 2). Makrozoobentos yang ditemukan di Kolam HSE DM lebih sedikit bila dibandingkan Kolam HSE MA yaitu sebanyak 4-7 taksa yang termasuk kelompok Insekta Akuatik, Ostracoda,
Gastropoda, Oligochaeta, dan Turbellaria (Gambar 1 \& 2). Taksa Corbicula, Helobdella, dan Placobdelloides hanya ditemukan di Kolam HSE MA, sedangkan taksa Filopaludina dan Dugesia hanya ditemukan di Kolam HSE DM. Taksa yang selalu ditemukan di kedua kolam setiap periode pengamatan adalah taksa Chironomidae, Dolerocypris, dan Oligochaeta (Gambar $3)$.

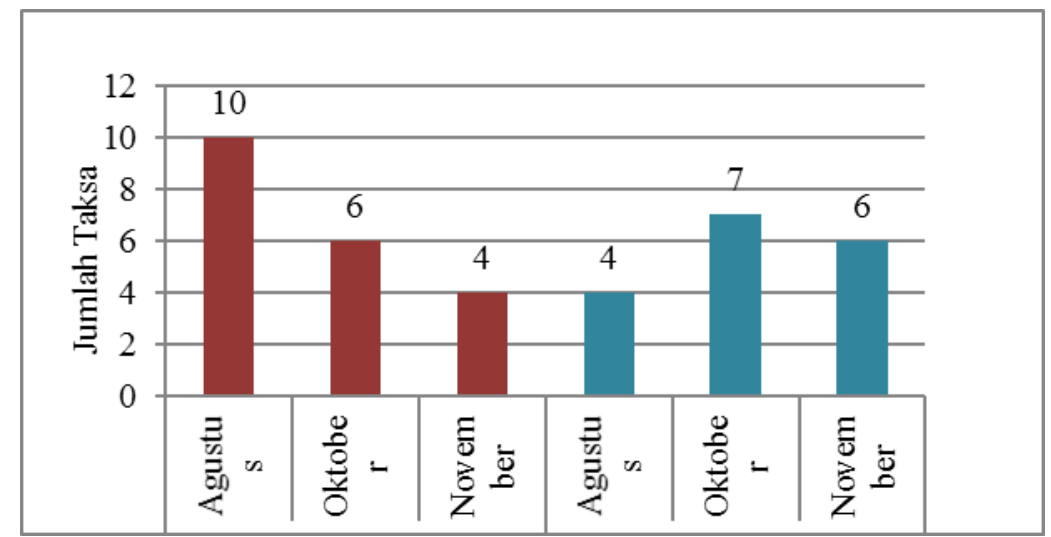

Gambar 1. Jumlah taksa makrozoobentos di Kolam HSE MA dan Kolam HSE DM periode Agustus-November 2018

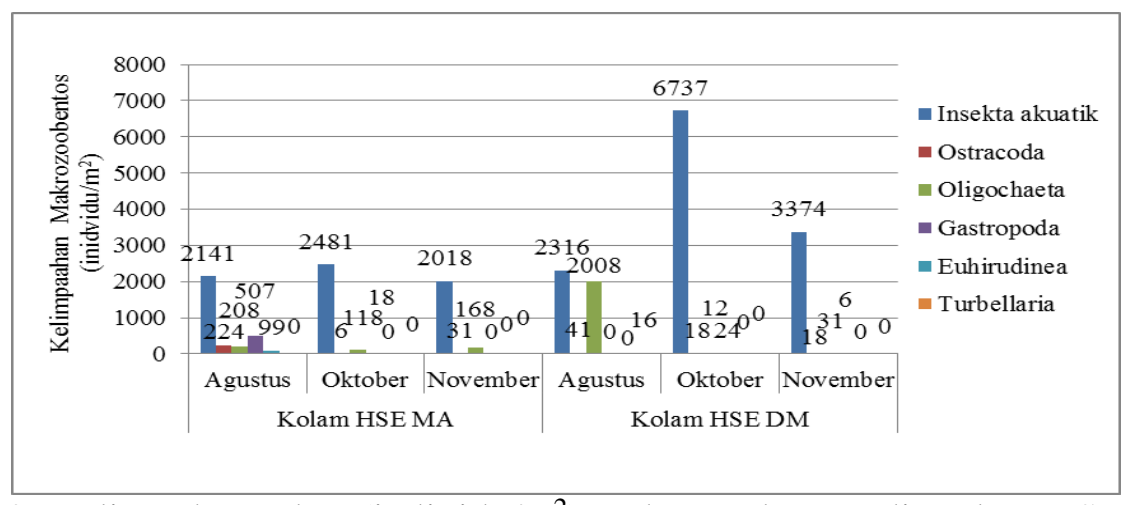

Gambar 2. Kelimpahan taksa (individu/ $\mathrm{m}^{2}$ ) makrozoobentos di Kolam HSE MA dan Kolam HSE DM periode Agustus-November 2018 
Kolonisasi Makrozoobentos pada ........Aiman I., Imroatushshoolikhah, Yoyok S., Lukman, Muhammad S. S.,...Sainmatika,...Volume 17,...No.1,...Juni 2020,...36-45

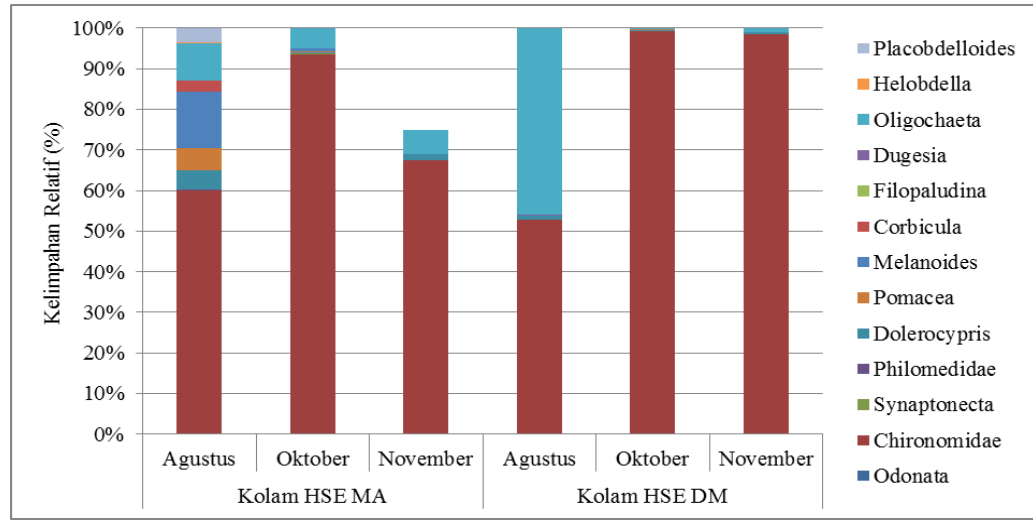

Gambar 3. Kelimpahan relatif (\%) makrozoobentos di Kolam HSE MA dan Kolam HSE DM periode Agustus-November 2018

Makrozoobentos yang ditemukan di Kolam HSE MA pada bulan Agustus hingga November 2018 memiliki kelimpahan taksa yang berkisar antara 2217-2623 individu $/ \mathrm{m}^{2}$, sedangkan makrozoobentos yang ditemukan di Kolam HSE DM memiliki kelimpahan taksa yang berkisar antara 3286-6791 individu $/ \mathrm{m}^{2}$. Pengamatan secara temporal pada kedua kolam HSE menunjukkan bahwa makrozoobentos ditemukan paling melimpah pada bulan Oktober 2018. Kelimpahan makrozoobentos pada kedua Kolam HSE menunjukkan tren peningkatan di bulan Oktober 2018, lalu mengalami penurunan pada bulan November 2018.

Taksa Chironomidae dari kelompok Insekta Akuatik selalu memiliki nilai kelimpahan tertinggi pada setiap periode pengamatan di kedua Kolam HSE. Hal ini sejalan dengan penelitian Reznickova et.al. (2016) yang menunjukkan bahwa larva Chironomidae sebagai makrozoobentos pengkoloni pionir yang paling melimpah pada kolam yang baru dibuat. Sulistiyarto dan Christiana (2015) menyatakan bahwa taksa Chironomidae yang berlimpah merupakan pengaruh gabungan dari ketersediaan sumber makanan dan perlindungan dari pemangsaan dalam suatu habitat. Insekta membentuk komponen penting dari rantai makanan dan jalur aliran energi dengan proporsi biomassa yang tinggi di ekosistem air tawar (Barman\& Baruah, 2015).

Tingginya kelimpahan larva Chironomidae dapat mendukung kehidupan ikan bada di kedua kolam sesuai pernyataan Sulastri dkk. (2011) bahwa Insekta Akuatik sebagai sumber makanan utama bagi ikan bada. Asyari (2006) menyatakan bahwa insekta dapat dimanfaatkan oleh beberapa ikan yang bersifat omnivora dan karnivora sebagai pakan utama atau pelengkap. Larva Chironomidae sebagai salah satu pakan alami ikan memiliki nutrisi yang sesuai kebutuhan ikan air tawar dengan kadar protein 48--55\% dan lemak $14 \%$ (Armitage, 1995). 
Kolonisasi Makrozoobentos pada ........Aiman I., Imroatushshoolikhah, Yoyok S., Lukman, Muhammad S. S.,...Sainmatika,...Volume 17,...No.1,...Juni 2020,...36-45

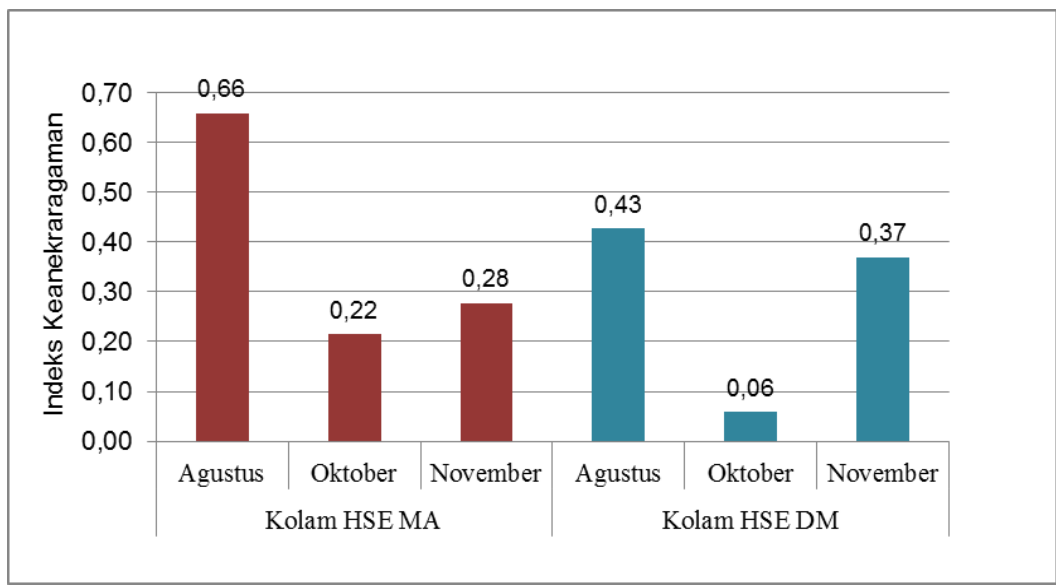

Gambar 4. Indeks keanekaragaman makrozoobentos di Kolam HSE MA dan Kolam HSE DM periode Agustus-November 2018

Nilai indeks keanekaragaman makrozoobentos di Kolam HSE MA berkisar $0,22-0,66$ yang tergolong kategori keanekaragaman rendah. Kategori keanekaragaman yang rendah diperoleh pula di Kolam HSE DM dengan nilai indeks yang berkisar 0,060,43 (Gambar 4). Nilai keanekaragaman di Kolam HSE DM relatif lebih rendah dibandingkan Kolam HSE MA. Nilai keanekaragaman tertinggi dan terendah di kedua Kolam HSE masing-masing diperoleh pada bulan Agustus dan Oktober 2018. Rendahnya keanekaragaman makrozoobentos di kedua Kolam HSE dipengaruhi oleh distribusi jumlah individu dari taksa makrozoobentos yang cenderung tidak merata atau terdapat dominasi dari taksa Chironomidae. Dominasi tersebutditandai dengan kelimpahan relatif taksa Chironomidae yang selalu menunjukkan nilai paling tinggi di kedua Kolam HSE pada setiap waktu pengamatan (Gambar $3)$.

Berdasarkan indeks similaritas Bray Curtis, Kolam HSE MAdan Kolam HSE DMmemiliki koefisien similaritas sebesar 0,63 pada bulan Agustus 2018. Koefisien similaritas yang diperoleh pada bulan Oktober dan November 2018 masing-masing sebesar 0,47 dan 0,62. Tingkat kesamaan komunitas yang mengkoloni kedua kolam HSE berkisar 47\%-63\%. Berdasarkan nilai indeks similaritas yang diperoleh, kedua kolam HSE tergolong kategori tidak mirip pada bulan Agustus 2018, sedangkan pada bulan Oktober dan November 2018 tergolong kategori mirip. Hal ini sesuai pernyataan Michael (1994) bahwa indeks similaritas tergolong kategori mirip bila memiliki nilai berkisar $50-75 \%$ dan tidak mirip bila memiliki nilai $25-50 \%$.

Kolonisasi makrozoobentos di habitat baru disebabkan oleh kemungkinan terjadinya mekanisme kolonisasi aerial berupa oviposisi telur oleh serangga dewasa dan penyebarannya oleh invertebrata non insekta (Tronstad et.al., 2007). Della Bella et.al. (2005) menjelaskan bahwa laju kolonisasi makrozoobentos pada kolam ikan dipengaruhi oleh faktor lokal seperti parameter fisik kimiawi air, komposisi stok ikan, tipe kolam ikan, fluktuasi air, saluran air, dan ketersediaan makanan. Keberadaan makrozoobentos di ekosistem kolam berperan penting sebagai sumber pakan utama untuk berbagai organisme predator (Broyer \& Curtet, 2010). 
Kolonisasi Makrozoobentos pada ........Aiman I., Imroatushshoolikhah, Yoyok S., Lukman, Muhammad S. S.,...Sainmatika,...Volume 17,...No.1,...Juni 2020,...36-45

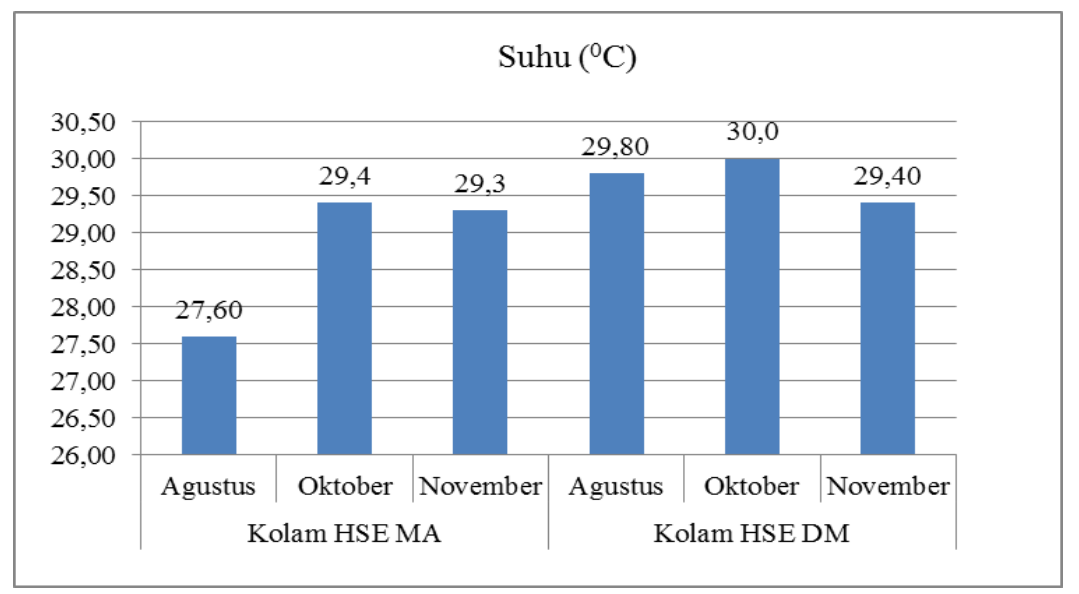

Gambar 5. Nilai parameter suhu di Kolam HSE MA dan Kolam HSE DM periode Agustus-November 2018

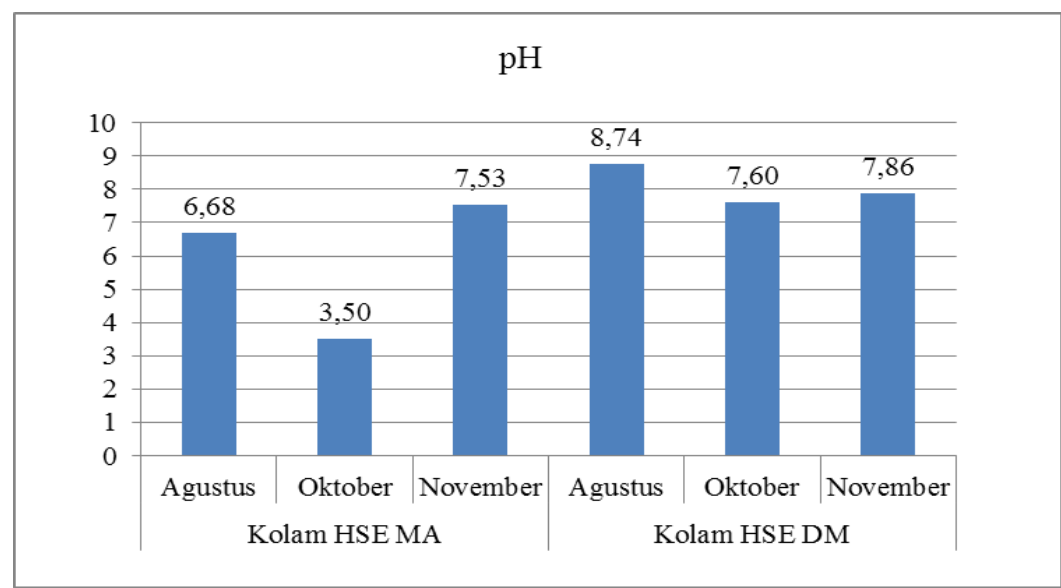

Gambar 6. Nilai parameter pH di Kolam HSE MA dan Kolam HSE DM periode Agustus-November 2018

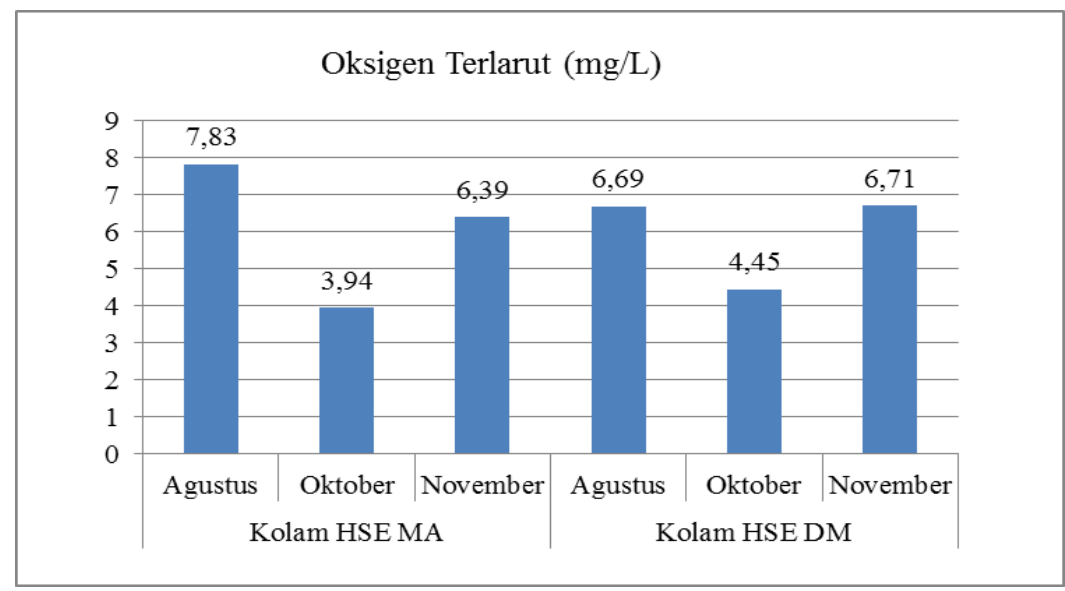

Gambar 7. Nilai parameter oksigen terlarut di Kolam HSE MA dan Kolam HSE DM periode Agustus-November 2018 
Parameter fisik kimiawi air kolam dapat mempengaruhi kehidupan makrozoobentos. Hasil pengukuran parameter fisik kimiawi air di kedua kolam dalam penelitian ini umumnya menunjukkan nilai yang dapat mendukung kelangsungan hidup makrozoobentos. Parameter suhu yang terukur berkisar $27,6^{\circ} \mathrm{C}-29,4^{\circ} \mathrm{C}$ di kolam HSE MA dan $29,4^{\circ} \mathrm{C}-30,0^{\circ} \mathrm{C}$ di kolam HSE DM (Gambar 5). Suhu ini tidak mempunyai pengaruh negatif terhadap kehidupan makrozoobentos karena menurut Hawkes (1979), suhu yang tidak lebih dari $30{ }^{\circ} \mathrm{C}$ tidak akan terlalu berpengaruh terhadap kehidupan makrozoobentos. Parameter $\mathrm{pH}$ yang terukur berkisar 3,50-7,53 di kolam HSE MA dan 7,60-8,74 di kolam HSE DM (Gambar 6). Effendi (2003) menyatakan $\mathrm{pH}$ biota akuatik menyukai $\mathrm{pH}$ berkisar 7-8,5. Kadar oksigen terlarut hasil penelitian menunjukkan kisaran 3,947,83 di kolam HSE MA dan 4,45-6,71 di kolam HSE DM (Gambar 7). Pescod (1973) menjelaskan bahwa kadar oksigen terlarut sebesar $2 \mathrm{mg} / \mathrm{L}$ dalam perairan sudah cukup mendukung kehidupan biota akuatik.

\section{KESIMPULAN}

Kolam HSE dengan sumber air mata air dikolonisasi oleh makrozoobentos yang meliputi Insekta, Ostracoda, Gastropoda, Oligochaeta, dan Euhirudinea. Kolam HSE dengan sumber air Danau Maninjau dikolonisasi oleh makrozoobentos yang meliputi Insekta, Ostracoda, Gastropoda, Oligochaeta, dan Turbellaria.Insekta Chironomidae yang memiliki kelimpahan tertinggi di kedua Kolam HSE berpotensi sebagai pakan alami ikan bada. Penelitian lanjutan dapat dilakukan dengan penambahan waktu pengambilan sampel di musim yang berbeda sehingga memperoleh data kolonisasiyang lebih lengkap.

\section{Ucapan Terima Kasih}

Penelitian ini merupakan bagian dari kegiatan Pusat Penelitian Limnologi, LIPI sesuai DIPA tahun 2018. Ucapan terima kasih kami sampaikan kepada tim pelaksana survei lapangan dan rekan teknisi di laboratorium yang sudah membantu dalam pengoleksian data dan preparasi sampel.

\section{DAFTAR PUSTAKA}

Armitage, P.D. (1995). Chironomidae as food. In P. D. Armitage, P. S. Cranston, \& L.C.V. Pinder (Ed.),The Chironomidae: Biology and Ecology of Non-Biting Midges. London: Chapman \& Hall.

Asyari. (2006). Peran Serangga Air Bagi Ikan Air Tawar. BAWAL, 1(2), 12-19.

Barman, A.\&Baruah, B. K. (2015). Macrophyte Preference and Aquatic Entomofaunal Diversity of Kapla Beel, A Fresh Water Wetland of Barpeta District of Assam, India. Asian Journal of Science And Technology,6 (03), 1205-1210.

Broyer J. \& Curtet, L. (2010). The Influence of Macrophyte Beds on Duck Breeding in Fishponds of The Dombes Region, France. Wildfowl,60, 136-149.

Della Bella, V., Bazzanti, M.,\& Chiarotti, F. (2005). Macroinvertebrate Diversity and Conservation Status of Mediterranean Ponds in Italy: Water Permanence and Mesohabitat Influence. Aquatic Conservation: Marine and Freshwater Ecosystems,15, 583600.

Edia, Oi Edia. (2013). Spatial and Circadian Variation of Aquatic Insect Communities in Three Tropical Fish Ponds (Natiokobadara, Korhogo, 
Kolonisasi Makrozoobentos pada ........Aiman I., Imroatushshoolikhah, Yoyok S., Lukman, Muhammad S. S.,...Sainmatika,...Volume 17,...No.1,...Juni 2020,...36-45

Northern Côte d'Ivoire).

International Journal of

Biosciences, 3(8), 22-30.

Effendi. (2003). Telaah Kualitas Air Bagi

Pengelolaan Sumber Daya dan

Lingkungan Perairan. Yogyakarta

: Kanisius.

Hawkes, H. A. (1979). Invertebrates as Indicator of River Water Quality. In A. James \& L. Evison (Ed.),Biological Indicators of Water Quality. New York : John Wiley \& Sons.

Klemm, D. J. (1995).Identification Guide to The Freshwater Leeches (Annelida:Hirudinea) of Forida and other Southern States. Florida

: Department of Environmental Protection.

Krebs, C.J. (1978). Ecology: The Experimental Analysis of Distribution and Abundance. New York: Harper \& Row Publisher.

Lee, C. D., Wang, S. B., \& Kuo, C. L. (1978).

Benthic

Macroinvertebrates and Fish as Indicators to Water Quality with Reference to Community Diversity Index. InE. A. R. Guano, B. N. Lokani,\&M. C. Thank(Ed.),Water Pollution Control in Development Countries. Thailand.

Loke, L. H. L., Clews E., Low E-wen, Belle, C. C., Todd, P. A., Eikaas H. S., \&Ng, P. K. L. (2010). Methods for Sampling Benthic Macroinvertebrates in Tropical Lentic Systems. Aquat Biol,10, 119-130.

Lukman. (2017). Perkembangan Pemanfaatan dan Penelitian Ikan Bada (Rasbora argyrotaenia) di Danau Maninjau. Warta Iktiologi, 1(1), 2427.

Mason, C. F. (1981). Biology of Freshwater Pollution. New York: Longman.
Michael, P.(1994). Metode Ekologi untuk Penyelidikan Ladang dan Laboratorium. Jakarta : UI Press.

Milner, A. M. (1994). Colonization and Succession of Invertebrate Communities in A New Stream in Glacier Bay National Park, Alaska. Freshwater Biology,32, 387-400.

Odum, E. P. (1996). Dasar-Dasar Ekologi. Edisi Ketiga. Yogyakarta : Gajah Mada University Press.

Orwa, P.O., Omondi, R.,\&Chemoiwa, E. J. (2018). Colonization Patterns of Benthic Macroinvertebrates in Fertilized and Non-Fertilized Earthen Fish Ponds. Int J Aquac Fish Sci, 4 (3), 022-026.

Pescod, N. B. (1973). Investigation of Rational Effluent and Stream for Tropical Countries. Bangkok : AIT.

Purwati, S. U. (2015). Karakteristik Bioindikator Cisadane : Kajian Pemanfaatan Makrobentik Untuk Menilai Kualitas Sungai Cisadane. Ecolab,9 (2),47-104.

Reznícková, P.,Petrovajová, V., Nerudová, J., Hadašová, L., \& Kopp, R.(2016). The Colonization of Newly Built Fishponds by The Macroinvertebrate Assemblages. Acta Universitatis Agriculturae Et Silviculturae Mendelianae Brunensis, 64 (16).

Soro, N., Camara, I. A., Edia, E. Oi., \&Diomand, D.(2018). Fishpond Colonization by Aquatic Macroinvertebrates: Case of Blondey (Côte d'Ivoire; West Africa). International Journal of Entomology Research, 3(6), 3441.

Sulastri,Hartoto, D. I., Yuniarti, I.,\& Nasution, S. H.(2011).Karakteristik Habitat, Kebiasaan Makan, dan Sistem Konservasi Ikan BadaRasbora argyrotaenia di Danau Maninjau. 
Kolonisasi Makrozoobentos pada ........Aiman I., Imroatushshoolikhah, Yoyok S., Lukman, Muhammad S. S.,...Sainmatika,...Volume 17,...No.1,...Juni 2020,...36-45

InProsiding Seminar Nasional

Ikan VI, Masyarakat Iktiologi

Indonesia (pp. 487-497).

Sulistiyarto, B. (2015). Pengukuran

Keanekaragaman

Makrozoobenthos di Perairan

Dataran Banjir Sungai Rungan

Kalimantan

Tengah

Menggunakan Substrat Buatan

dari Ijuk. Jurnal Ilmu Hewani

Tropika, 4 (2).

Sulistiyarto, B.\& Christiana, I.(2015).

Colonization by Bloodworms

(Chironomidae Larvae) using

Artificial Substrates in Floodplain

Waters: Effect of Exposure

Periods and Season. International

Journal of Aquatic Science, 6(2), 39-47.

Tronstad, L. M.,Tronstad, B. P.,\& Benke, A. C.(2007). Aerial Colonization and Growth: Rapid Invertebrate Responses to Temporary Aquatic Habitats in A River floodplain. $J$. N. Am. Benthol. Soc., 26(3), 460471.

Yule, C.M. \&Sen, Y. H. (2004). Freshwater Invertebrates of The MalaysianRegion. Kuala lumpur : Academy of Science Malaysia. 